\title{
Phenotypic Screening and Molecular Characterization of 10 Rice (Oryza sativa) Landraces for Cold Tolerance
}

\author{
M. Shoroardi ${ }^{1 *}$, M. G. Mortuza ${ }^{1}$, M. M. Islam ${ }^{2}$ and T. Samiha ${ }^{1}$ \\ ${ }^{1}$ Department of Biochemistry and Molecular Biology, Bangladesh Agricultural University, \\ ${ }^{2}$ Plant Breeding Division, Bangladesh Institute of Nuclear Agriculture \\ *Corresponding author: ali10bau@gmail.com
}

\begin{abstract}
Phenotypic screening of existing 10 familiar landraces performed at germination and seedling stages and their molecular characterization were conducted at Bangladesh Institute of Nuclear Agricultural (BINA) during the period of December 2014 to May 2015 to screen out better cold tolerant genotypes among 10 landraces where one susceptible, two moderately tolerant and two tolerant BRRI released varieties were used as check genotypes. The present study evaluated several parameters at the germination stage after 7 days of germination and at the seedling stage after 28 days of seedling growth for phenotypic screening. Modified hydroponic method was used at the seedling stage and the temperature treatments were maintained artificially at $15^{\circ} \mathrm{C}$ and $25^{\circ} \mathrm{C}$ respectively. Polymorphic microsatellite or SSR markers were selected for molecular characterization showing that attributes were positively regulated due to cold stress in BRRIdhan 36, LR 114- Badiabona and LR 54- Tor Balam. The findings of genetic diversity analysis for landraces LR 114- Badiabona and LR 54- Tor Balam appeared to resemble to that of tolerant genotype BRRIdhan 36. Based on phenotypic screening and UPGMA dendrogram study, landraces LR 114- Badiabona and LR 54- Tor Balam appeared superior as genetic material. Better cold tolerant rice variety may be developed from further breeding process.
\end{abstract}

Key words: Modified hydroponic method, Polymorphism information content, Sustained water bath, SSR marker and UPGMA dendogram

\section{Introduction}

Cold stress is a significant problem for rice production in temperate and high altitude tropical regions. At temperatures below $15-20{ }^{\circ} \mathrm{C}$, rice plants exhibit a wide range of chilling injury depending on the length of exposure and the developmental stage (Zhang et al., 2005). Tolerance is a complex trait as evidenced by the wide range of responses to low temperature stress. Genetic studies using mapping populations, typically from inter-subspecific crosses (japonica and indica), have identified a number of cold tolerance quantitative trait loci (QTLs), supporting the involvement of several genes (Han et al., 2006). Bangladesh is endowed with a great diversity of rice landraces in its vast traditional land area. After green revolution the traditional rice landraces were almost eliminated and sustained by high yielding varieties. Landraces provided "adaptability genes" for specific environmental conditions. Incorporation of adaptability genes from landraces could ensure optimum grain yield for the region.

Microsatellite or simple sequence repeat (SSR) markers are considered to be appropriate for assessment of genetic diversity and variety identification because of their ability to detect large numbers of discrete alleles repeatedly, accurately and efficiently. Microsatellite markers have been ideal for identification and purity checking of rice varieties (Singh et al., 2004), characterization of genetic diversity in cultivated (Zhang et al., 2009) and wild rice (Juneja et al., 2006) and also more distantly related grass species (Ishii and McCouch, 2000). A random set of microsatellite markers should facilitate an unbiased assay of genetic diversity and unambiguous molecular description of rice genotypes. Considering the importance, the present study was conducted to understand genetic variation of 15 rice genotypes which are genetically diverse and previously been used in breeding programs because of their wide range of agronomic attributes.

The specific objectives of the study include: to screen the rice genotypes phenotypically under normal and cold stressed condition at the seedling stage; to make DNA fingerprint and genetic relationship among 15 rice genotypes using SSR marker; to identify the cold tolerant rice genotypes.

\section{Materials and Methods}

\section{Experimental site and period}

Experiments were conducted at the glasshouse, experimental field and Laboratory of Biotechnology Division, Bangladesh Institute of Nuclear Agriculture (BINA), Mymensingh during the period of December 2014 to May 2015.

\section{Collection of germplasms}

A total of 15 rice genotypes were used. Ten experimental landraces viz. LR 171- Sokou Malsira, LR 150- Hekha, LR 167- Kala Dgopa, LR 114- Badiabona, LR 01- Dudh Kalam, LR 212- Naria Bochi, LR 25Kathi Goccha, LR 37- Hamai, LR 54- Tor Balam and LR 101- Dud Sail were collected from the Seed Gene Bank of Biotechnology division, BINA, BAU Campus, Mymensingh-2202. Beside those, other 5 varieties were used as check varieties including one susceptibleBRRIdhan 28, two moderately tolerant- BRRIdhan 55 \& BRRIdhan 57 and two tolerant- BRRIdhan 36 and BRRIdhan 29 collected from BRRI, Joydebpur-1701.

\section{Experimental setup}

Modified Hydroponic system (Gregorio et al., 1997) was used at the glasshouse and the field to evaluate cold tolerance of the 18 rice germplasms using Peter's solution (Yoshida et al., 1976).

A special kind of seedling floats was prepared using cork sheet and a rectangular glass fiber tray with $12-\mathrm{L}$ capacity and diameter of 23 inch was used to fit the 
floats. Peters water soluble fertilizer (Urea: TSP: $\mathrm{MP}=20: 20: 20)$ and ferrous sulphate $\left(\mathrm{FeSO}_{4} \cdot 7 \mathrm{H}_{2} \mathrm{O}\right)$ were used as nutrient solution that mixed in plastic containers. The $\mathrm{pH}$ of the solution was monitored daily and maintained around 5.1 because \pm 1.0 deviation of culture solution $\mathrm{pH}$ from 5.0 makes some nutrients toxic and others deficient. For the maintenance of cold environment, seedling floats were placed on the experimental tables in the field and ice crystals and cold water were dissolved with nutrient solution to reach the desired temperature level which was maintained at $15^{\circ} \mathrm{C}$. The solution was replaced with the new one in every 8 day and the $\mathrm{pH}$ was maintained at 5-5.5 daily.

After breaking dormancy, seeds were washed and rinsed with tap water and then placed on petridishes with moistened filter papers and incubated for 48 hours at $30^{\circ} \mathrm{C}$ to germinate. In case of treatment, seeds were washed and rinsed with tap water and then placed on petridishes with moistened filter papers and kept in laboratory where the average temperature was maintained at $15-20^{\circ} \mathrm{C}$. 20 pre-germinated seeds of each genotypes were placed in two rows and thus 5 genotypes can be placed per seedling float. Then the experimental trays are placed in the glasshouse as control and in the field for screening cold stress.

Phenotypic screening of cold tolerance at the germination stage

To conduct the phenotypic screening at germination stage, germination percentage and seedling survival rate are calculated. 20 seeds and 20 germinated seedlings were brought under test for each under control and stressed condition.

The vigor of seed germination was recorded after 7 days for both control and treatment following the given formula:

Number of germinated grains

Germination $(\%)=$

Number of total grains given for germination

Seedling survival rates were assessed after 7 days of growth at both normal growth and cold stressed condition which can be calculated as follows:

$$
\text { Seedling survival rate }(\%)=\frac{\text { Surviving Seedlings }}{\text { Number of budding seeds }} \times 100
$$

Phenotypic screening of cold tolerance at seedling stage

Three seedlings of each genotype were selected randomly and the height of each plant was measured from base of the shoot to the tip of the main stem, root length from the shoot initiation to the root tip, total length from the root tip to the shoot tip, fresh weight and dry weight at the age 28 days of the seedling stage were also observed. The mean values were recorded and expressed in particular units. After imposition on cold stress, seedling growth scale was scored using standard evaluation system (SES) for rice. Extent of damage was determined at both normal and cold stressed condition at about $15^{\circ} \mathrm{C}$ on 1 to 9 scales standardized for rice (IRRI, 1996). 1 indicating dark green seedlings, 3 indicating light green seedlings, 5 indicating yellow seedlings, 7 indicating brown seedlings and 9 indicating dead seedlings.

\section{DNA fingerprinting of rice genotypes using SSR marker}

DNA extraction from 21-25 day old plant leaves was done at the Biotechnology Lab of BINA, Mymensingh using the mini preparation Cetyl Trimethyl Ammonium Bromide (CTAB) method. The simplified mini scale procedure for DNA isolation in Polymerase Chain Reaction (PCR) analysis developed in IRRI was followed. The quality of the isolated DNA in the protocol is sufficient for the PCR analysis (Zheng et al., 1995).

Young vigorously growing fresh leaf samples from these seedlings were collected from 25 day old seedlings to extract genomic DNA. Microsatellite markers or SSRs are valuable for tagging and mapping of cold tolerance genes. Three random primers viz. RM140, RM215 and RM510 were selected to evaluate 15 rice genotypes for cold tolerance (Table 1 ).

Table 1. Microsatellite markers (SSRs) used for molecular characterization

\begin{tabular}{|c|c|c|c|c|c|c|c|}
\hline \multirow{2}{*}{$\begin{array}{l}\text { Primer } \\
\text { Name }\end{array}$} & \multirow{2}{*}{$\begin{array}{l}\text { Physical } \\
\text { Location } \\
(\mathrm{Mb})\end{array}$} & \multicolumn{2}{|c|}{ Primer Sequence $\left(5^{\prime} 3^{\prime}\right) \rightarrow$} & \multirow{2}{*}{$\begin{array}{l}\text { Primer } \\
\text { Size (bp) } \\
\text { (For, Rev) }\end{array}$} & \multirow{2}{*}{$\begin{array}{l}\text { Repeat } \\
\text { Motif }\end{array}$} & \multirow{2}{*}{$\begin{array}{l}\text { Anneali } \\
\text { ng } \\
\text { Temp. } \\
\left({ }^{0} \mathrm{C}\right)\end{array}$} & \multirow{2}{*}{$\begin{array}{l}\text { Expected } \\
\text { PCR } \\
\text { Product } \\
\text { Size (bp) } \\
\end{array}$} \\
\hline & & $\begin{array}{l}\text { Forward } \\
\text { Primer } \\
\text { Sequence } \\
\end{array}$ & $\begin{array}{ll}\text { Reverse } & \text { Primer } \\
\text { Sequence } & \end{array}$ & & & & \\
\hline RM140 & 12.30 & $\begin{array}{l}\text { TGCCTCTTCC } \\
\text { CTGGCTCCCC } \\
\text { TG }\end{array}$ & $\begin{array}{l}\text { GGCATGCCGAA } \\
\text { TGAAATGCATG }\end{array}$ & 22,22 & $(\mathrm{CT}) 12$ & 55 & 261 \\
\hline RM215 & 27.90 & $\begin{array}{l}\text { CAAAATGGA } \\
\text { GGCAGCAAG } \\
\text { AGC }\end{array}$ & $\begin{array}{l}\text { TGAGCACCTCC } \\
\text { TTCTCTGTAG }\end{array}$ & 20,22 & $(\mathrm{CT}) 16$ & 55 & 148 \\
\hline RM510 & 2.83 & $\begin{array}{l}\text { AACCGGATTA } \\
\text { GTTTCTCGCC }\end{array}$ & $\begin{array}{l}\text { TGAGGACGACG } \\
\text { AGCAGATTC }\end{array}$ & 20,20 & (GA) 15 & 55 & 122 \\
\hline
\end{tabular}

The PCR cocktail was prepared for amplification of products based on IRRI rice protocol for SSR analysis and the total volume of PCR cocktail for this study was $8 \mu 1$ per sample (Table 2). $2 \mu 1$ genomic DNA was added 
with $8 \mu 1$ PCR cocktail and finally the total volume was made $10 \mu \mathrm{l}$ which were placed in the PCR tubes and run in the DNA thermal cycler (Table 3).

Table 2. Components of PCR cocktail for SSR

\begin{tabular}{lll}
\hline Sl. No. & Components & Quantity, for single reaction $(\boldsymbol{\mu l})$ \\
\hline 1 & $10 X$ Taq Buffer A & 1.0 \\
2 & $\mathrm{MgCl}_{2}$ & 1.0 \\
3 & dNTPs & 1.0 \\
4 & Primer Forward & 1.0 \\
5 & Primer Reverse & 1.0 \\
6 & Taq polymerase & 0.12 \\
7 & ddH $_{2} \mathrm{O}$ & 3.88 \\
\hline & Total & $\mathbf{8 . 0}$ \\
\hline
\end{tabular}

Table 3.Thermal profile for SSR

\begin{tabular}{r}
\hline Thermal profile for SSR \\
\hline I. \\
II. \\
III. \\
\\
IV. \\
V. \\
VI.
\end{tabular}

The amplified PCR products were mixed with $2 \mu$ of 2X gel loading dye and electrophoresis was done and after that, the gel was taken out carefully from the gel chamber and transferred in ethidium bromide solution for staining and documentation. The images that appeared on the computer were saved for scoring.

Polyacrylamide Gel Electrophoresis shows some advantage over agarose gel electrophoresis. Its main

Initial denaturation at $94^{\circ} \mathrm{C}$ for $5 \mathrm{~min}$

Denaturation at $94^{\circ} \mathrm{C}$ for $1 \mathrm{~min}$

Annealing at respective temperature of individual primer for $1 \mathrm{~min}$

Polymerization at $72^{\circ} \mathrm{C}$ for $2 \mathrm{~min}$

Cycle to step 2 for 34 more time

Incubation at $72^{\circ} \mathrm{C}$ for $7 \mathrm{~min}$

\section{Statistical analysis of phenotypic data}

Percent reduction was calculated using the following formula: Traits of normal - Traits in treatment

$\%$ reduction $=$

Traits in normal

advantage over agarose is that acrylamide has smaller pores making it better suited for separating smaller DNA molecules that agarose gel would not be able to separate.

The gel image resolution was adjusted using the camera setting. The gel was exposed to UV light and the gel image was saved as a jpg file.

MSTATC software was used to perform data analysis on phenotypic data for normal and cold stressed environments.

\section{SSR Data Analysis}

The pattern of bands obtained after application with the primers was scored with reference of control. The size (in nucleotide base pairs) of the amplified band for each microsatellite marker was determined based on its migration relative to a molecular weight size marker (25 bp DNA Ladder) with the help of Alpha Ease FC 5.0 software. The summary statistics including the number of alleles per locus, major allele frequency, gene diversity and polymorphism information content (PIC) values were determined using POWER MARKER version 3.23 (Liu and Muse, 2005), a genetic analysis software. Molecular weights for microsatellite products, in base-pairs, were estimated with Alpha Ease $4 \mathrm{C}$ software. The individual fragments were assigned as alleles of the appropriate microsatellite loci.

Allele molecular weight data also used to determine the genetic distance for phylogeny reconstruction based on neighbor-joining method (Saitou and Nei's 1983) as implemented in POWER MARKER with the tree viewed using TREEVIEW.

\section{Results and Discussion}

\section{The phenotypic performance of rice landraces}

Data collected for this experiment were: germination percentages $(\%)$, seedling survival rate $(\%)$ at germination stage; shoot length $(\mathrm{cm})$, root length $(\mathrm{cm})$, total height of plants $(\mathrm{cm})$, fresh weight $(\mathrm{g})$, dry weight $(\mathrm{g})$, seedling growth scale at seedling stage which are shown in table 4 . Data were analyzed statistically for the identification of which landraces were effective against cold stress. Comparison between phenotypic performances of rice genotypes under control and treatment condition at seedling stage is shown in fig. 1 . 


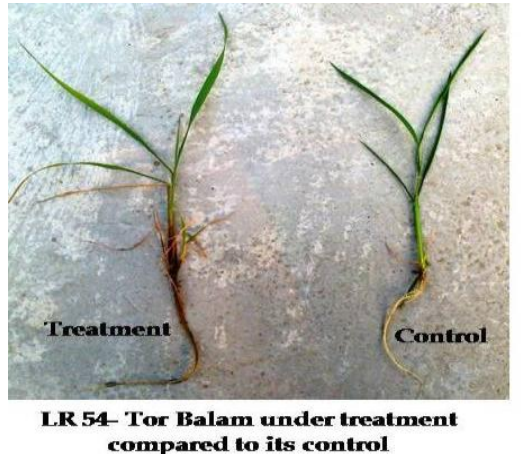
compared to its control

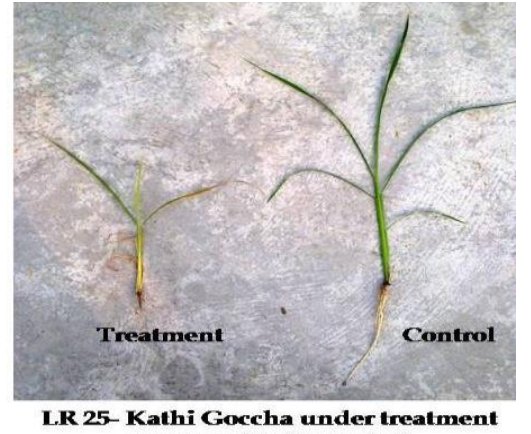

compared to its control

Fig. 1. Comparison between phenotypic performances of rice genotypes under control and treatment condition

A higher reduction in germination percentages was observed in BRRIdhan 28, LR 212- Naria Bochi and LR 25- Kathi Goccha genotypes compare to their corresponding controls whereas a lower reduction was observed in BRRIdhan 36, LR 54- Tor Balam and LR 114- Badiabona genotypes. BRRIdhan 28, LR 212Naria Bochi andLR 25- Kathi Goccha genotypes showed a higher percent reduction in seedling survival rate whereas a lower reduction was observed in BRRIdhan 36, BRRIdhan 29, LR 54- Tor Balam and LR 114- Badiabona genotypes. A higher percent reduction in shoot length was found in BRRIdhan 28, LR 212- Naria Bochi and LR 25- Kathi Goccha genotypes compare to their corresponding controls whereas a lower reduction were observed in BRRIdhan 36, BRRIdhan 29, LR 54- Tor Balam and LR 114Badiabona genotypes. BRRIdhan 28, LR 212- Naria Bochi andLR 25- Kathi Goccha genotypes indicated a higher percent reduction in root length whereas a lower reduction was observed in BRRIdhan 36, LR 114Badiabona and LR 54- Tor Balam genotypes.

A higher percent reduction in fresh weight was found in BRRIdhan 28, LR 01- DudhKalam, LR 212- Naria Bochi andLR 25- Kathi Goccha genotypes whereas a lower reduction was observed in BRRIdhan 36, BRRIdhan 29, LR 114- Badiabona and LR 54- Tor Balam genotypes. BRRIdhan 28, LR 01- Dudh Kalam, LR 212- Naria Bochi and LR 25- Kathi Goccha genotypes indicated a higher percent reduction in dry weight whereas a lower reduction were observed in BRRIdhan 36, BRRIdhan 29, LR 114- Badiabona and LR 54- Tor Balam genotypes. The highest growth scale was 7 which recorded in BRRIdhan 28, LR 212- Naria Bochi and LR 25- Kathi Goccha in treatment condition and the lowest value was 1 which recorded in all control rice genotypes.

Table 4. Percent reduction study of the phenotypic traits under control and treatment condition

\begin{tabular}{|c|c|c|c|c|c|c|c|c|}
\hline Genotypes & $\begin{array}{l}\text { Percent } \\
\text { Germina } \\
\text { tion }(\%)\end{array}$ & $\begin{array}{l}\text { Seedling } \\
\text { survival } \\
\text { rate }(\%)\end{array}$ & $\begin{array}{l}\text { Shoot } \\
\text { length } \\
\text { (cm) }\end{array}$ & $\begin{array}{l}\text { Root } \\
\text { length } \\
\text { (cm) }\end{array}$ & $\begin{array}{l}\text { Total } \\
\text { height } \\
\text { (cm) }\end{array}$ & $\begin{array}{l}\text { Fresh } \\
\text { weight } \\
\text { (g) }\end{array}$ & $\begin{array}{l}\text { Dry } \\
\text { weight } \\
\text { (g) }\end{array}$ & $\begin{array}{l}\text { Seedling } \\
\text { growth } \\
\text { scale }(\mathrm{cm})\end{array}$ \\
\hline BRRIdhan 36 & 20.67 & 5.00 & 6.45 & 6.39 & 6.45 & 9.92 & 7.02 & 1 \\
\hline BRRIdhan 29 & 15.67 & 15.00 & 16.13 & 22.22 & 16.13 & 17.80 & 15.15 & 1 \\
\hline BRRIdhan 28 & 18.33 & 52.63 & 47.49 & 43.94 & 47.49 & 52.12 & 54.84 & 7 \\
\hline BRRIdhan 55 & 22.33 & 31.58 & 23.97 & 19.36 & 23.97 & 26.85 & 24.49 & 3 \\
\hline BRRIdhan 57 & 21.67 & 27.78 & 23.68 & 21.44 & 23.68 & 23.54 & 29.79 & 3 \\
\hline LR 171- SokouMalsira & 24.67 & 21.05 & 26.18 & 27.27 & 26.18 & 28.46 & 26.15 & 5 \\
\hline LR 150- Hekha & 21.67 & 27.78 & 34.36 & 35.30 & 34.36 & 29.25 & 30.19 & 3 \\
\hline LR 167- Kala Dgopa & 24.50 & 38.89 & 50.23 & 51.34 & 50.23 & 43.37 & 41.54 & 5 \\
\hline LR 114- Badiabona & 21.33 & 15.79 & 13.28 & 13.30 & 13.28 & 16.75 & 14.06 & 1 \\
\hline LR 01- DudhKalam & 23.33 & 41.18 & 43.91 & 43.23 & 43.91 & 48.59 & 48.39 & 5 \\
\hline LR 212- NariaBochi & 24.00 & 52.94 & 56.07 & 59.98 & 56.07 & 56.78 & 55.38 & 7 \\
\hline LR 25- KathiGoccha & 21.33 & 55.56 & 56.31 & 57.55 & 56.31 & 57.29 & 56.67 & 7 \\
\hline LR 37- Hamai & 19.33 & 37.50 & 34.74 & 40.55 & 34.74 & 36.90 & 38.46 & 5 \\
\hline LR 54- Tor Balam & 24.67 & 5.88 & 14.05 & 15.00 & 14.05 & 14.93 & 16.67 & 1 \\
\hline LR 101- Dud Sail & 22.67 & 37.50 & 35.93 & 37.19 & 35.93 & 35.45 & 36.07 & 3 \\
\hline $\mathrm{LSD}_{0.05}$ & 8.30 & 9.75 & 2.29 & 1.22 & 3.40 & 0.22 & 0.07 & 1.19 \\
\hline Level of significance & *** & $* *$ & ** & *** & $* *$ & ** & ** & ** \\
\hline CV $(\%)$ & 21.81 & 17.06 & 16.71 & 18.00 & 16.55 & 18.20 & 18.73 & 66.07 \\
\hline Minimum & 40 & 40 & 8.33 & 4.67 & 14.00 & 0.82 & 0.26 & 1.00 \\
\hline Maximum & 100 & 100 & 24.67 & 13.33 & 38.00 & 2.30 & 0.72 & 7.00 \\
\hline Mean & 72.17 & 76.5 & 18.35 & 9.12 & 27.47 & 1.60 & 0.50 & 2.40 \\
\hline Standard Error & 2.88 & 5.21 & 2.59 & 1.40 & 3.70 & 0.21 & 0.07 & 0.21 \\
\hline Standard Deviation & 15.74 & 19.03 & 4.69 & 2.46 & 7.05 & 0.43 & 0.14 & 2.11 \\
\hline
\end{tabular}




\section{Molecular characterization of rice genotypes using SSR markers}

The genetic variations of 15 rice genotypes were analyzed by using 3 SSR primers (RM140, RM215 and RM510) a total of 17 alleles were detected among 15 rice genotypes. The average number of allele per locus was 5.667 with a range of 4 (RM510) to 8 (RM215). No rare allele was observed at all of the SSR loci of the 15 rice genotypes/varieties. Totally absent of allele indicates null allele. In this experiment the average value of null allele was 0.333. RM140 marker generates null allele. The polymorphism information content (PIC) value provides an estimate of discriminating power of a marker based on the number of alleles at a locus and relative frequencies of these alleles. The PIC values in this study varied from 0.407 (RM510) to 0.787 (RM215) with an average of 0.651 (Table 5).

Table 5. Data of "summary statistics-I" for 3 microsatellites (SSR) markers

\begin{tabular}{|l|l|l|l|l|l|l|l|}
\hline Locus & $\begin{array}{l}\text { Sample } \\
\text { size }\end{array}$ & $\begin{array}{l}\text { Allele size } \\
\text { ranges (bp) }\end{array}$ & Differences & $\begin{array}{l}\text { No. of } \\
\text { allele }\end{array}$ & $\begin{array}{l}\text { /Rare } \\
\text { allele }\end{array}$ & $\begin{array}{l}\text { Null } \\
\text { allele }\end{array}$ & PIC \\
\hline RM140 & 15.0 & $207-236$ & 29.0 & 5.0 & 0.0 & 1.0 & 0.760 \\
\hline RM215 & 15.0 & $121-160$ & 39.0 & 8.0 & 0.0 & 0.0 & 0.787 \\
\hline RM510 & 15.0 & $106-150$ & 44.0 & 4.0 & 0.0 & 0.0 & 0.407 \\
\hline Mean & 15.0 & - & 37.333 & 5.667 & 0.0 & 0.333 & 0.651 \\
\hline
\end{tabular}

According to Nei's (1983) the highest level of genetic diversity (0.809) was observed in loci RM215 and the lowest level of genetic diversity (0.436) was observed in loci RM510 with a mean diversity of 0.679 which is stated in table 6 . It was observed that marker detecting the lower number of alleles showed lower gene diversity than those detected higher number of alleles which revealed higher gene diversity.

Table 6. Data of "summary statistics-II" for 3 microsatellites (SSR) markers

\begin{tabular}{|l|l|l|l|l|l|}
\hline \multirow{2}{*}{ Locus } & \multicolumn{2}{|l|}{ Major allele } & $\begin{array}{l}\text { Genotype } \\
\text { no. }\end{array}$ & Availability & $\begin{array}{l}\text { Gene } \\
\text { diversity }\end{array}$ \\
\cline { 2 - 6 } & Size (bp) & Frequency (\%) & 6.0 & 1.0 & 0.791 \\
\hline RM140 & 215 & 26.7 & 8.0 & 1.0 & 0.809 \\
\hline RM215 & 148 & 33.3 & 4.0 & 1.0 & 0.436 \\
\hline RM510 & 106 & 73.3 & 6.0 & 1.0 & 0.679 \\
\hline Mean & 156.333 & 44.4 &
\end{tabular}

The UPGMA cluster analysis is led to the grouping of the 15 rice genotypes/varieties in three major clusters (Fig. 2). The UPGMA cluster analysis of genetic distance indicated that all 10 landraces could be easily distinguished based on the information generated by the 3 SSR markers. The genotypes were BRRI dhan $36=\mathrm{G} 1$

BRRI dhan $29=\mathrm{G} 2$

BRRI dhan $28=\mathrm{G} 3$

BRRI dhan $55=\mathrm{G} 4$

BRRI dhan $57=$ G5

LR 171- Sokou Malsira= G6

LR 150- Hekha= G7

LR 167- Kala Dgopa= G8

Table 7. Categorization of 15 genotypes in 3 clusters

\begin{tabular}{|l|l|l|}
\hline Cluster Number & \% Genotypes & Genotypes \\
\hline I & 20.0 & G2, G14, G15 \\
\hline II & 13.333 & G3, G4 \\
\hline III & 66.667 & G11, G12, G10, G13, G1, G5, G9, G6, G7, G8 \\
\hline Total & 100.0 & 15 Rice genotypes \\
\hline
\end{tabular}

The present study addressed the utilization of SSR markers, to determine genetic diversity and relationship among the landraces at molecular level. The genetic diversity determined in this study will help in the selection of cold tolerant separated in three clear groups (Table 7). The 3 SSR markers also allowed the distinction among the genotypes studied.

For understanding easily the full name of 15 rice genotypes are denoted as follows:

LR 114- Badiabona= G9

LR 01- Dudh Kalam= G10

LR 212- Naria Bochi= G11

LR 25- Kathi Gocha= G12

LR 37- Hamai= G13

LR 54- Tor Balam $=$ G14

LR 101- Dud Sail = G15 


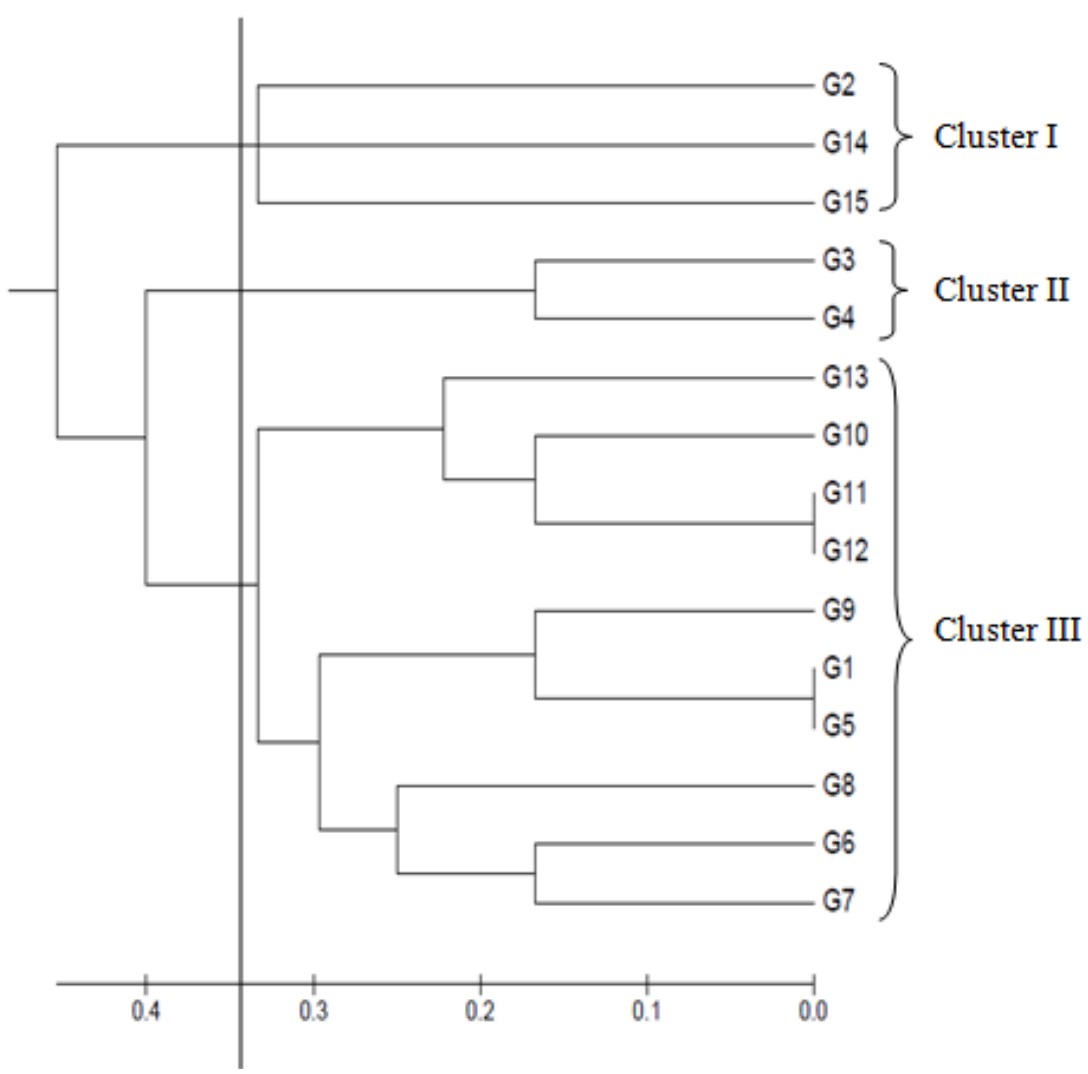

Fig. 2. UPGMA dendogram based on Neies (1983) genetic distance summarizing the differentiation among 15 rice germplasms according to SSR analysis. (Arrow line indicates the scale of genetic distance (0.00-0.45)

\section{Conclusion}

The present investigations helped to establish clearcut identity of all the landraces under consideration, which will be a great utility for the selection of cold tolerant landraces as genetic materials to release a new cold tolerant variety suited for the cold affected region of Bangladesh during winter season.

Considering important morphological characters at both germination and seedling stages and from UPGMA dendrogram it is concluded that LR 114- Badiabona and LR 54- Tor Balam were the best among all the 10 landraces. These genotypes can be used for field trial for releasing new cold tolerant varieties based on further breeding program.

\section{References}

Gregorio, G. B.; Senadhira, D. and Mendoza, R. T. 1997. Screening rice for salinity tolerance. IRRI. Discussion Paper series 22, IRRI, Manila. 30.

Han, L. Z.; Zhang, Y. Y.; Qiao, Y. L.; Cao, G. L.; Zhang, S. Y.; Kim, J. H. and Koh, H. J. 2006. Genetic and QTL analysis for low-temperature vigor of germination in rice. Genetic Science, 33(11): 998-1006.

IRRI (International Rice Research Institute). 1996. Standard Evaluation System for rice. 4th ed. Int. Network for Genetic Evaluation of Rice, Genetic Resource Center, Los Baños, The Philippines. p.
52. IRGSP. 2005. The map based sequence of the rice genome. Nature, 436: 793-800.

IRRI. 2013. Annual Report for 2013. Los Banos, Laguna, Philippines. 525 p.

Ishii, T. and McCouch, S. R 2000: Microsatellites and microsynteny in chloroplast genomes of Oryza and eight other Gramineae species. Theoretical and Applied Genetics, 100: 1257-1266.

Juneja, S.; Das, A. and Joshi, S. V. 2006. Oryzanivara Sharma and Shastry, the progenitor of $O$. sativa $\mathrm{L}$. subspecies indica harbors rich genetic diversity as measured by SSR markers. Current Science, 91: 1079-1085.

Liu, K.; and Muse, S. V. 2005. Power Marker: Integrated analysis environment for genetic marker data. Bioinformatics, 21: 2128-2129.

Nei, M. 1983. Analysis of gene diversity in subdivided populations. Proceedings of the National Academy of Sciences, 70: 3321-3323.

Saitou, N. and Nei, M. 1983. The neighbor-joining method: a new method for reconstructing phylogenetic trees. Molecular Biology and Evolution, 4: 406-425.

Singh, R. K. and Sharma, R. K. 2004. Suitability of mapped sequence tagged microsatellite site markers for establishing distinctness, uniformity and stability in aromatic rice. Euphytica, 135: 135143. 
Yoshida, S.; Forno, D. A.; Cook, J. H. and Gomez, K. A. 1976. Laboratory manual for physiological studies of rice. Los Banos, Laguna, Philippines: International Rice Research Institute (IRRI), 6166.

Zhang, Z. H.; Chen, L. H. and Zhu, Y.G. 2005. Comparison of QTL controlling seedling vigour under different temperature conditions using recombinant inbred lines in rice (Oryza sativa). Annals of Botany, 95(3): 423-429.

Zhang, D. and Zhang, H. 2009. Genetic structure and differentiation of Oryza sativa L. in China revealed by microsatellites. Theoretical and Applied Genetics, 119: 1105-1117.

Zheng, K.; Huang, N.; Bennet, J. and Khush, G. S. 1995. PCR-based marker assisted selection in rice breeding. International Rice Research Institute (IRRI), Loss Banos, Laguna. Philippines, 1-24. 